Demis, D. J., Brown, C. S., and Crosby, W. H. (1964). Amer. J. Med., 37, 195.

(196nd, K. N., Michael, A. F., Good, R. A., and Vernier, R. L. (1964), 7. Pediat., 65, 1114.

iles, H. MCC., Pugh, R. C. B., Darmady, E. M., Stranack, F., and Woolf, L. I. (1957). Arch. Dis. Childh, 32, 167.

Goodman, H. C., Wolff, S. M., Carpenter, R. R.; Andersen, B. R., Brandriss, M. W. (1963). Ann. intern. Med., 59, 388.

Gotoff, S. P., Fellers, F. X., Vawter, G. F., Janeway, C. A., and Rosen, F. S. (1965). New Engl. ₹. Med., 273, 524. Greenman, L., Weigand, F. A., and Danowski, T. S. (1955). Amor. F.

Haggerty, R. J., Maroney, M. W., and Nadas, A. S. (1956). Ibid., 92, 535.

Hardwicke, J. (1965a). 7. clin. Path., 18, 559.

- (1965b). Clin. chim. Acta, 12, 89.

and Soothill, J. F. (1961). In Ciba Foundation Symposium on Renal Biopsy, edited by G. E. W. Wolstenholme, and M. P. Cameron, p. 32. Churchill, London.

Harrison, C. V., Loughridge, L. W., and Milne, M. D. (1964). Quart. 7. Med., 33, 39.

Hill, R. D., and Scott, G. W. (1964). Brit. med. F., 1, 370.

Hitzig, W. H., Auricchio, S., and Benninger, J. H." (1965). Klin. W schr., 43, 1154.

Joachim, G. J., Cameron, J. S., Schwartz, M., and Becker, E. L. (1964). 7. clin. Invest., 43, 2332 .

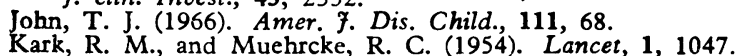

Keliey, V. C., and Panos, T. C. (1952). F. Pediat., 41, 505.

Kellum, R. E., and Haserick, J. R. (1963). Arch. Derm., 87, 289.

Lagrue, G., Bariety, J., de Kérautem, Y., Samarca, P., Fritel, D., de Boisdeffre, B., and Milliez, P. (1964)." F. Urol. Néphrol., 70, 156.
Fritel, D., Tcherdakoff, P. G., Bariety, J., Samarcq, P., and Milliez, P. (1962). Sem. Hôp. Paris, 38, 425.

Lancet, 1965, 2, 473 .

Lestina, F. A., Freedman, S., and Wilson, H. (1953). 7. Lab. clin. Med., 42, 918 .

McClusky, R. T., Vassali, P., Gallo, G., and Bald'win, D. S. (1966). N. Engl. F. Med., 274, 696 .

Michael, A. F., Drummond, K. N., Vernier, R. L., and Good, R. A. (1964). Pediat. clin. N. Amer., 11, 685.

Milliez, P., Lagrue, G., and Bariety, J. (1965). Bull. Acad. nat. Med. (Paris), 149, 259.

Payet, M., Sankale, E., Moulanier, M., and Diop, B. (1964). Thérapie, $19,921$.

Pearl, M. A., Burch, R. R., Carvajal, E., McCracken, B. H., Woody, H. B., and Sternberg, W. H. (1963). Arch. intern. Med., 112, 716 .

Peters, J. H. (1963). In Biochemical Clinics No. 2: The Kidney, Peters,
edited by H. Reuben, p. 137. Donnelly, New York.

Riley, C. M., and Scaglione, P. R. (1959). Pediatrics, 23, 561.

Russell, P. J., Hicks, J. D., and Burnet, F. M. (1966). Lancet, 1, 1279.

Saxena, K. M., and Crawford, J. D. (1965). Amer. Heart 7., 70, 835.

Shearn, M. A. (1965). New Engl. F. Med., 273, 943.

Soothill, J. F. (1962). F. Lab. clin. Med., 59, 859.

Talamo, R. C., and Crawford, J. D. (1963). New Eng!. F. Med., 269, 15. Taylor, R., Corcoran, A. C., and Page, I. H. (1950). F. Lab. clin. Med.,

36, 996. (1958). Amer. F. Dis. Child., 95, 498.

West, C. D. (1958). Amer. F. Dis. Child., 95, 498. N. H. (1965a). F. Pediat., 67, 1089 .

Holland, N. H., McConville, J. M., and McAdams, A. J. (1965b). Ibid., 67, 1113.

Hong, R., and Holland, N. H. (1966). Ibid., 68, 516

White, R. H. R. (1963). Arch. Dis. Childh., 38, 260.

\title{
Tetanus in Childhood: Report of a Therapeutic Trial of Diazepam
}

\author{
R. G. HENDRICKSE,* M.D., F.R.C.P.ED.; P. M. SHERMAN, $\dagger$ M.B., B.S., D.C.H.
}

Brit.med. F., 1956, 2, 860-862

The clinical management of tetanus poses a difficult therapeutic problem to physicians everywhere. Mortality from the disease remains high even in those medical centres endowed with the best facilities currently available. In many developing countries where the disease is prevalent, and medical services are inadequate for local needs, mortality figures are alarmingly high, especially among cases of neonatal tetanus (Tompkins, 1958 ; Loh Siew Gek, 1951). In these circumstances any innovation in treatment that offers some hope of reducing mortality from the disease is worthy of trial, especially if it is simple, relatively inexpensive, and safe.

Diazepam (Valium) has two distinct pharmacological properties-tranquillizing and muscle-relaxant. In experimental work the drug has been shown to block spinal reflexes in anaesthetized cats (Randall et al., 1961), and it has been used with benefit in the management of the "stiff-man syndrome," which previously was unamenable to any form of treatment (Howard, 1963). These facts suggested that diazepam might be of value in the management of tetanus, and in October 1964 a therapeutic trial was started. Preliminary findings were encouraging (Hendrickse and Sherman, 1965). The trial has since been completed, and this report summarizes our findings.

\section{Material and Methods}

When the trial started in October 1964 all new cases of tetanus seen in the Department of Paediatrics were randomly allocated into one of three treatment groups designated $\mathrm{A}, \mathrm{B}$, and $C$.

The following standard treatment was given to all groups: (1) paraldehyde by intramuscular injection for immediate con-

\footnotetext{
* Professor and Head of Department of Paediatrics, University College Hospital. Ibadan. + Research Fellow
}

trol of spasms ; (2) anti-tetanus serum, 20,000 to 50,000 units, by intramuscular injection: (3) penicillin, 150,000-300,000 units daily, for five days ; (4) as soon as initial sedation was secured with paraldehyde a gastric tube was passed through the nose, and subsequent medication was administered by this route during the early days of treatment ; and (5) additional antibiotics-for example, tetracycline-were used for complications such as bronchopneumonia.

The following regimens of sedation were then employcd in the different groups:

Group A: Phenobarbitone, 4.4-6.6 mg. $/ \mathrm{kg}$., and chlorpromazine 1.1-2.2 mg. $/ \mathrm{kg}$. six-hourly.

Group B: Phenobarbitone and chlorpromazine as in group A, plus diazepam, 0.44-1.1 mg. $/ \mathrm{kg}$. six-hourly.

Group C: Diazepam only; up to $1.1 \mathrm{mg} . / \mathrm{kg}$. six-hourly.

The clinical course of all patients was recorded on a special form. The data recorded were summarized at the end of each 24-hour period, and sedation was modified, if necessary, in the light of the patient's progress. Routine administration of phenobarbitone, chlorpromazine, and diazepam was by the nasal tube, injections being given only where specially indicated.

Following our observations on the first 26 cases admitted to the trial that diazepam on its own appeared to be not very effective in controlling convulsive spasms during the early phase of treatment, it was decided to eliminate group C. From March 1965, therefore, cases were randomly allocated into groups A and B only.

Between October 1964 and October 1965199 childien under 10 years of age were admitted with the diagnosis of tetanus. Of this number 149 are included in this report. The 50 patients who have been excluded are those who (a) were seen during three brief periods when the trial was temporarily suspended, or (b) fell into our original Group C, or (c) could not be validly assessed either because their records were incomplete 
or because their management had not conformed to our protocol.

All cases were graded as either "mild to moderate" or "severe." This assessment was made on first examination in most cases. When this grading had not been made initially it was made retrospectively by considering the number and severity of spasms in the first hours. Children having more than 20 spasms recorded in the first 24 hours were graded as "severe."

\section{Results}

There were 104 cases of neonatal tetanus and 45 cases of tetanus in older children in the series as a whole.

\section{Neonatal Tetanus}

There were 53 cases in group A, of which 14 were graded mild to moderate and 39 severe (Table I). The number of deaths in each grade was 2 and 27 respectively. The corresponding figures for group B were total cases 51, mildmoderate 18 with 4 deaths, severe 33 with 24 deaths. The overall mortality in groups A and B was identical (55\%).

TABLE I.-Neonatal Tetanus. Mortality in Two Treatment Groups

\begin{tabular}{c|c|c|c|c|c}
\hline \multirow{2}{*}{ Group } & \multicolumn{2}{|c|}{ Mild-Moderate } & \multicolumn{2}{|c|}{ Severe } & Overall \\
\cline { 2 - 5 } & $\begin{array}{c}\text { No. of } \\
\text { Cases }\end{array}$ & Deaths & $\begin{array}{c}\text { No. of } \\
\text { Cases }\end{array}$ & Deaths & Mortality \\
\hline A (53 total) & 14 & 2 & 39 & 27 & $55 \%$ \\
B (51 total) & 18 & 4 & 33 & 24 & $55 \%$ \\
\hline
\end{tabular}

A number of the deaths in both groups were not directly related to tetanus, and in many instances death occurred at a time when the patients were obviously recovering from tetanus. Table II shows mortality directly attributable to tetanus, and Table III gives details of these deaths excluded from Table II. The "corrected" mortality was $41 \%$ in both groups.

\begin{tabular}{c|c|c|c|c|c}
\multicolumn{1}{c}{ TABLB II.- “ Corrected" Mortality for Neonatal Tetanus } \\
\hline \multirow{3}{*}{ Group } & \multicolumn{2}{|c|}{ Mild-Moderate } & \multicolumn{2}{|c|}{ Severe } & Mortality \\
\cline { 2 - 5 } & $\begin{array}{c}\text { No. of } \\
\text { Cases }\end{array}$ & Deaths & $\begin{array}{c}\text { No. of } \\
\text { Cases }\end{array}$ & Deaths & \\
\hline A & 14 & - & 39 & 22 & $41 \%$ \\
\hline B & 18 & 1 & 33 & 20 & $41 \%$ \\
\hline
\end{tabular}

TABLe III.-Neonatal Tetanus. Deaths Not Directly Atributable to

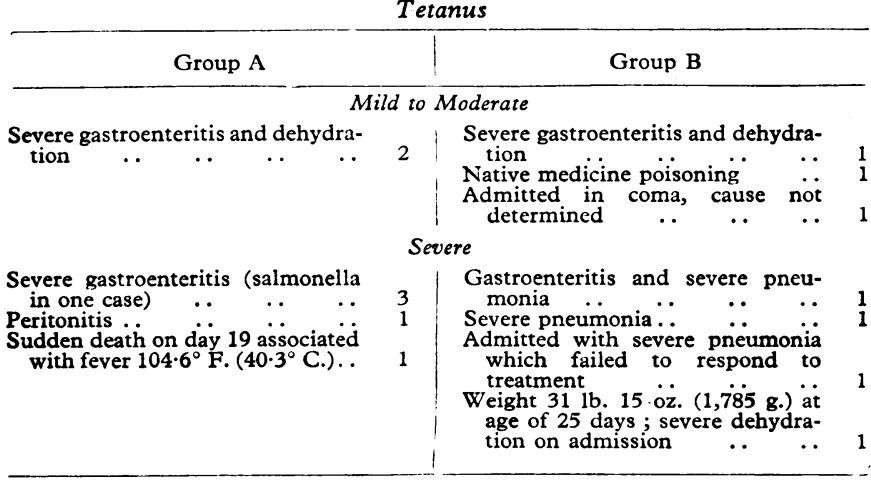

Table IV shows the distribution of cases in groups A and B in relation to the age of onset of symptoms and the mortality in each age group. It will be noted that there are no significant differences between groups $\mathrm{A}$ and $\mathrm{B}$. In both groups mortality is significantly higher among cases with an earlier age of onset of symptoms. This finding is in agreement with that previously recorded by other observers (Hines, 1930 ; Tompkins, 1958).
TABLE IV.-Neonatal Tetanus. Age of Onset in Relation to Mortality*

\begin{tabular}{|c|c|c|c|c|c|}
\hline Day of Onset (after Birth) & & $2-4$ & $5-7$ & $8-10$ & 11 and \\
\hline $\begin{array}{l}\text { Group A }\left\{\begin{array}{l}\text { No. of cases } \\
\text { Deaths } \\
\text { No. of cases } \\
\text { Deaths }\end{array} \text { Group B }\right. \\
\% \text { Mortality group A } \ldots \\
" \text { " combined groups A and } \\
\text { ". } \ldots\end{array}$ & $\begin{array}{l}\because \\
\because \\
\because \\
\ddot{B} \\
\ddot{*}\end{array}$ & $\begin{array}{r}4 \\
3 \\
3 \\
2 \\
75 \\
67 \\
71\end{array}$ & $\begin{array}{l}29 \\
18 \\
27 \\
18 \\
62 \\
67 \\
64\end{array}$ & $\begin{array}{r}12 \\
6 \\
9 \\
1 \\
50 \\
11 \\
33\end{array}$ & $\begin{array}{r}5 \\
1 \\
6 \\
2 \\
20 \\
33 \\
27\end{array}$ \\
\hline
\end{tabular}

- Three cases in group A and six cases in group B have been excluded, as the age of onset of symptoms could not be ascertained with reasonable certainty.

Comparison of temperature records in 43 cases in group $A$ and 44 in group $B$ showed that there was no difference between maximum temperatures recorded; $23 \%$ in each group had maximum temperatures of $103^{\circ} \mathrm{F}$. $\left(39.4^{\circ} \mathrm{C}\right.$.) or more at some stage in their disease (Table V). Comparison of lowest temperatures recorded in the two groups, however, revealed differences. Temperatures of $95^{\circ} \mathrm{F} .\left(35^{\circ} \mathrm{C}\right.$.) or less were recorded in 19 cases in group $A(44 \%)$ and in 33 cases in group B $(75 \%)$. These differences are statistically significant $\left.\chi^{2}=7.35, P=0.01^{1}\right)$. The mortality among children with temperatures of $95^{\circ} \mathrm{F}$. or less was $58 \%$ in group A and $45 \%$ in group B. These differences are not statistically significant.

TABLB V.-Comparison of Maximum and Minimum Temperatures in Groups $A$ and $B$

\begin{tabular}{|c|c|c|c|c|}
\hline \multirow{2}{*}{ Group } & \multirow[t]{2}{*}{$\begin{array}{l}\text { Total No. } \\
\text { of Cases* }\end{array}$} & \multirow{2}{*}{$\frac{\begin{array}{c}\text { Max. Temp. } \\
103^{\circ} \mathrm{F} .\left(39 \cdot 4^{\circ} \mathrm{C} .\right) \\
\text { or More }\end{array}}{\text { No. of Cases }}$} & \multicolumn{2}{|c|}{$\begin{array}{c}\text { Min. Temp. } 95^{\circ} \mathrm{F} .\left(35^{\circ} \mathrm{C} .\right) \\
\text { or Less }\end{array}$} \\
\hline & & & No. of Cases & No. of Deaths \\
\hline $\begin{array}{l}\mathbf{A} \\
\mathbf{B}\end{array}$ & $\begin{array}{l}43 \\
44\end{array}$ & $\begin{array}{l}10(23 \%) \\
10(23 \%)\end{array}$ & $\begin{array}{l}19(44 \%) \\
33(75 \%)\end{array}$ & $\begin{array}{l}11 \\
15\end{array}$ \\
\hline
\end{tabular}
* Seventeen patients who died early in the course of the disease had incomplete
temperature records and have been excluded from this analysis.

\section{Tetanus in Older Children}

There were 22 cases in group A ; 12 mild-moderate with five deaths and 10 severe with six deaths. Corresponding figures for group B were: total $23 ; 17$ mild-moderate with four deaths and six severe with two deaths. The overall mortality in group A was $50 \%$ and in group B $26 \%$ (Table VI).

Several deaths in both groups were not directly attributable to tetanus. The "corrected" mortality is shown in Table VII and the reasons for excluding deaths in Table VIII.

\begin{tabular}{|c|c|c|c|c|c|}
\hline \multirow{2}{*}{ Group } & \multicolumn{2}{|c|}{ Mild-Moderate } & \multicolumn{2}{|c|}{ Severe } & \multirow{2}{*}{ Mortality } \\
\hline & No. of Cases & Deaths & No. of Cases & Deaths & \\
\hline$\underset{\mathrm{B}}{\mathrm{A}}$ & $\begin{array}{l}12 \\
17\end{array}$ & $\begin{array}{l}5 \\
4\end{array}$ & $\begin{array}{c}10^{*} \\
6\end{array}$ & $\begin{array}{l}6 \\
2\end{array}$ & $\begin{array}{l}50 \% \\
26 \%\end{array}$ \\
\hline \multicolumn{6}{|c|}{$\begin{array}{l}\text { Two patients who recovered had diazepam added to their sedation on day } 6 \text { and } \\
\text { respectively to relieve opisthotonos. }\end{array}$} \\
\hline TABLB V & - Correct & 1"Mo & ality from 1 & inus in & Older Childre \\
\hline \multirow{2}{*}{ Group } & \multicolumn{2}{|c|}{ Mild-Moderate } & \multicolumn{2}{|c|}{ Severe } & \multirow{2}{*}{ Mortality } \\
\hline & No. of Cases & Deaths & No. of Cases & Deaths & \\
\hline $\begin{array}{l}\mathrm{A} \\
\mathrm{B}\end{array}$ & $\begin{array}{l}12 \\
17\end{array}$ & 2 & $\begin{array}{r}10 \\
6\end{array}$ & $\begin{array}{l}5 \\
2\end{array}$ & $\begin{array}{r}32 \% \\
9 \%\end{array}$ \\
\hline
\end{tabular}

The differences in mortality between groups $\mathrm{A}$ and $\mathrm{B}$ indicate that on the whole children in group B fared better than those in group A. The difference in the overall mortality in the two groups is, however, not statistically significant. The difference in the "corrected " mortality between the groups, though more marked, is also not statistically significant.

${ }^{1}$ Yates correction applied. 
TABle VIII.-Deaths Not Directly Attributable to Tetanus

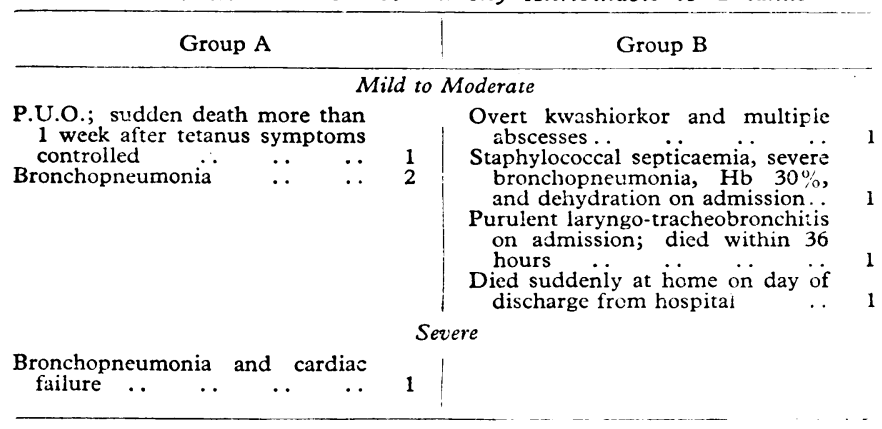

\section{Comment on Action of Diazepam}

Diazepam appeared to be of most value in cases of tetanus in which tonic spasm of muscles was marked but convulsive spasms were infrequent. It was effective in relieving trismus and opisthotonos in the majority of cases, at the dose of $4.4 \mathrm{mg} . / \mathrm{kg} . / 24$ hours.

The oral rout of administration was used almost exclusively in this trial and appeared to be perfectly satisfactory. Our limited experience of the intramuscular route of administration does not suggest that this has any special advantage over oral administration.

The intravenous route of administration was tried on a few occasions and did not appear to produce a dramatic onset of action of the drug.

No toxic effects attributable to diazepam were observed in either neonates or older children. The lower temperatures revealed among neonates who received diazepam, however, suggest that it tends to induce hypothermia. Mortality was not adversely affected by this action of the drug.

\section{Summary and Conclusions}

Results of therapeutic trial of diazepam in tetanus are reported. The trial included 149 patients-104 neonates and 45 older children. Patients were randomly allocated into two treatment groups, one of which received diazepam in addition to the standard treatment used in both groups.

In neonatal tetanus the mortality rate was unaffected by the use of diazepam, but the drug was of value in relieving tonic muscle spasm, in particular trismus.

A significant number of patients who received diazepam had minimum temperatures of $95^{\circ} \mathrm{F}$. $\left(35^{\circ} \mathrm{C}\right.$.) and lower, but did not appear to be adversely affected by this.

In older children with tetanus the overall mortality rate was lower among those who received diazepam than among those who did not, but the difference is not statistically significant. As in neonates, the drug was of value in relieving tonic spasm but did not seem to have any direct effect on convulsive spasms.

Findings in this trial indicate that diazepam is a useful drug in the management of tetanus, principally because of its ability to reduce tonic muscle spasm. Its use appears to be free of toxic effects or unpleasant side-actions. In older children it may have favourably influenced mortality from the disease.

\section{REFERENCES}

Hendrickse, R. G., and Sherman, P. M. (1965). Lancet, 1, 737.

Hines, E. A. (1930). Amer. F. Dis. Child., 39, 560

Hines, E. A. (1930). Amer. F. Dis. Child., 39, 560.

Howard, F. M. (1963). Proc. Mayo Clin., 38, 203.

Loh Siew Gek (1951). Med. F. Malaya, 5, 181 . Boris, A., Moe, R. A., and Abrams, W. B. (1961). Curr. ther. Res., 3, 405 .

Tompkins, A. B. (1958). Brit. med. f., 1, 1382

\title{
Experience with Diazepam in Tetanus
}

\author{
D. FEMI-PEARSE,* M.B., M.R.C.P.ED., D.T.M.\&H.
}

Brit. med. 7., 1966, 2, 862-865

The mortality from tetanus is still high in many parts of the world (Jelliffe, 1950 ; Johnstone, 1958 ; Tompkins, 1958, 1959 ; Adams et al., 1959 ; Smythe, 1963 ; Kloetzel, 1963). However, an encouraging report by Ellis (1963) claimed that in the Leeds Tetanus Unit there had been no deaths among 36 cases treated in the previous four years; all except two mild cases were treated with curare (total paralysis) and positive-pressure artificial respiration. Such a method of treatment is beyond the scope of most hospitals in the developing countries, where there are, among other problems, shortages of equipment and expert medical personnel. Simpler methods of treatment therefore continue to be tried.

Cole and Robertson (1955) and Gelfand (1955) reported the successful abolition of spasms by chlorpromazine in tetanus patients. Kelly and Laurence (1956) substantiated this finding by abolishing spasms in rabbits having experimental tetanus, and proceeded to treat a $2 \frac{1}{2}$-year-old boy successfully with the drug.

Weinberg (1964) successfully treated severe tetanus in a $6 \frac{1}{2}$ year-old boy weighing $17.4 \mathrm{~kg}$. with diazepam in doses varying

\footnotetext{
- Department of Medicine, Lagos University Teaching Hospital, P.M.B. 12003, Lagos, Nigeria. Present address: University of Rochester School of Medicine and Dentistry and Strong Memorial Hospital, Rochester, New York.
}

between 30 and $40 \mathrm{mg}$. every 24 hours. Hendrickse and Sherman (1965), in a preliminary report of a therapeutic trial of diazepam and chlorpromazine in neonates and children, found diazepam to be useful in tetanus, but could not draw definite conclusions because of the small number in their series.

Prior to its use in tetanus, diazepam had been found useful in treating skeletal-muscle spasms associated with conditions such as overriding fractures of the femur and tibia (Kestler, 1963); stiff-man syndrome (Howard, 1963); cervical and lumbar disc protrusion (Bain, 1964); and in the relief of spasticity in patients with upper-motor-neurone lesions (Leavitt et al., 1963).

Diazepam is a tranquillizer and muscle-relaxant of the 1,4-benzodiazepine group. We have used this drug in the treatment of tetanus at the Lagos University Teaching Hospital with a view to assessing its value and shortcomings in the management of the disease. This paper describes our present experience.

\section{Materials and Methods}

Forty-two patients (19 males and 23 females) with tetanus were studied. Their ages ranged from 4 days to 50 years. Twenty-nine received diazepam from the time of admission, 